\title{
THOUGHTS ON VISITOR DEVELOPMENT AT THE WORKERS MUSEUM IN COPENHAGEN
}

\author{
SØREN BAK-JENSEN \\ Director of The Workers Museum
}

The Workers Museum in Copenhagen (Arbejdermuseet) was closed for more than two months in Spring 2020 due to the COVID-19 pandemic. While we are relieved that the lockdown seems to have put the country in control of the spreading of the disease, the lack of revenues from tickets, gift shop, café, and venue hire has left the museum in serious economic difficulties.

As a consequence, we are watching visitor flow very closely at the moment. But rather than focusing on general visitor numbers, the museum has focused on the composition of the visitors. The main reason for this is our concern over demographic inequalities in museum visitors in Denmark. A national study from 2018 found that $56 \%$ of the adult population in Denmark visit museums infrequently and almost $40 \%$ do not visit museums at all. Infrequent users and non-users form a diverse group if age, sex, and geography are taken into account. However, members of this group usually share one characteristic - short educational background. This national pattern also applies to the visitors of The Workers Museum.

Inequalities reflected in the visitor profile of The Workers Museum raises serious questions about the appeal of the museum and our understanding of the target groups. And for the museum sector in general, failing to be relevant to a specific part of the population undermines the claim that museums enhance communality and citizenship.

Therefore, we have tried to make The Workers Museum relevant to new target groups in a number of ways. One way has been to place great emphasis on the educational programs that are mainly aimed for children and young people. The Workers Museum is among the 25 most visited museums in Denmark. But when it comes to visits from schools, we are in the top five. This contributes to a greater diversity in visitors. Through cooperation with schools, we may help to foster and strengthen people's familiarity with museums, and we reach a very broad audience in terms of socio-cultural backgrounds.

Another approach is related to The Workers Museum's public programs and to the ways we develop them. Our most ambitious example so far of this is the ongoing project "Clever Hands" which involves an exhibition, a teaching program, and a series of events and workshops. The project takes its starting point in the need for more young people to choose vocational education, and it aims to give insight into the daily life and working conditions of craftsmen during recent decades. The project was developed with trained craftsmen and, also, with young people about to make their choice of education. All with the intention of making the project relevant and attractive to people with short educational backgrounds. 


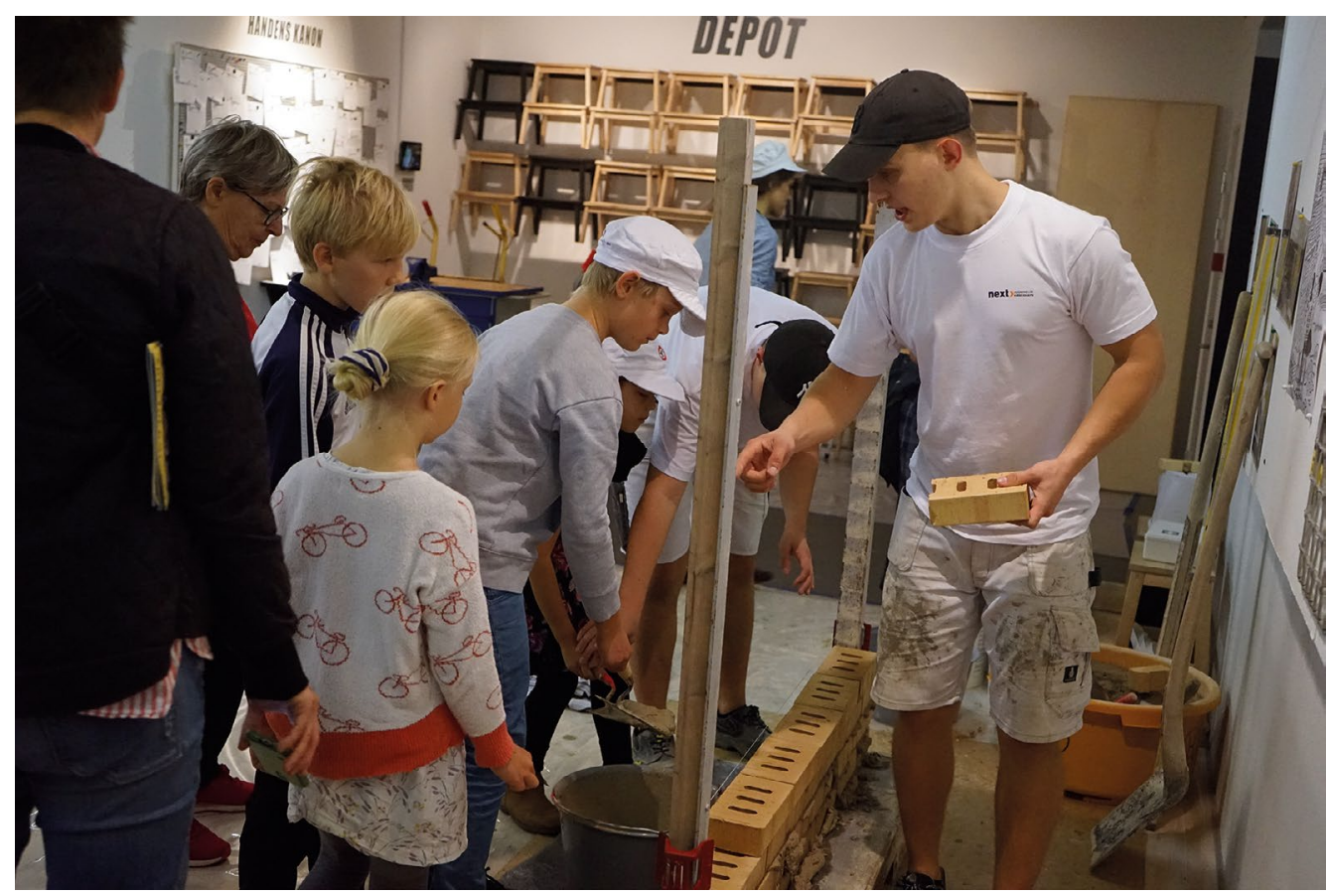

Young bricklayers from technical schools in Copenhagen conduct workshops at The Workers Museum. Photo: Arbejdermuseet.

Due to unusually generous support by private foundations, we have been able to put a lot of resources into the project. And we do have noticed that the composition of the visitors to the museum is evolving for the better. The massive effort that has been made in order to form ties with new user groups has been an important lesson to us. And in a crisis like the one brought about by COVID-19, it may be difficult to find resources - or the courage to allocate resources. Still, I believe that especially for labour history museums, rooted as many of them are in a radical democratic tradition, it is especially important today to prioritize inclusion. If museums have fewer visitors in the future because of the COVID-19 restrictions, it is more important than ever that they are for everyone. 